\title{
DETERMINANTS OF LEADING OF ORGANIC FARMS IN MALOPOLSKA REGION
}

Renata MATYSIK-PEJAS, Institute of Economics and Enterprises Management, Faculty of Agriculture and Economics, University of Agriculture in Krakow, Address: Al. A. Mickiewicza 21, 31-120 Krakow, Poland, rrmatysi@cyf-kr.edu.pl (corresponding author) Monika SZAFRAŃSKA, Institute of Economics and Enterprises Management, Department of Economics and Corporate Finance, Faculty of Agriculture and Economics, University of Agriculture in Krakow, Address: Al. A. Mickiewicza 21, 31-120 Krakow, Poland, m.szafranska@ur.krakow.pl

Elżbieta LATO, owner of organic farm in Malopolska Voivodeship; elalato@o2.pl

Poland is a country with significant potential for the development of organic farming. This is due to the possession of rural areas characterized by favorable natural and productive conditions. The advantages of Polish agriculture include relatively clean environment, low chemicals consumption, large labor resources and relatively low labor costs. The main objective of conducted research was to present factors determining the leading of organic farms in the conditions of fragmented agriculture in south Poland. The research was conducted in the Malopolska Voivodeship in 2017. Source material for analysis was primary information collected using PAPI method. In the survey participated 50 certified organic farms chosen by using purposive method of sample selection. In the area structure of surveyed organic farms dominated farms from 5.1 ha to 10 ha. The most popular direction of agricultural production on farms was the growing vegetables. Owners of organic farms as one of the main reasons for moving the farm from conventional to organic systems, considered the possibility of obtaining subsidies for one hectare of cultivation. These subsidies provide them financial support especially in the first years of operation on the market. The least important reason for transformation a farm from conventional to organic system was the factor associated with the reduction of environmental pollution as a result of the change in system of farming. As one of the advantages of running a organic farm, producers pointed the possibility of selecting disease-resistant plant and animal species and creating additional workplaces. On the other hand, as a basic disadvantage of organic farming, farmers pointed out the difficulties in finding market for the products from the farm. Most farm owners cooperate with various organizations connected with ecology. Very popular among them are also different kind of training courses, which are aimed at expanding knowledge of organic production. At the same time the educational activity of the surveyed farms is very low. Only in a few farms was conducted educational activity for children or people interested in ecology.

Keywords: organic farms, Małopolska

\section{INTRODUCTION}

Organic farming is currently a quickly developing system in the European Union countries. It is a farming system with possibly balanced plant and animal production within a holding based on natural (biological and mineral) technologically unprocessed resources. Its main principle is lack of use of agricultural, chemical, and veterinary chemical agents. It stimulates natural resources and biological production mechanisms of holdings, assuring long-term soil fertility, and the high biological quality of agricultural produce. It is the most sustainable system in terms of ecology, as it is not harmful for the environment, economy (it is largely independent on external outlays), and sociology, as it allows rural areas and agriculture to survive as social and cultural categories (Soltysiak, 1994). Among the basic objectives of organic farming, those related to maintaining biological diversity (genetic wealth), the production of food rich in nutritional values, and the ability to provide appropriate to agricultural producers (Kozlowski, 2000) should be emphasised. Another objective of organic farming is the maximum reduction of human impact on the environment through conducting this farming system in a natural way (Weglarzy, Bereza, 2010).

Poland has a great potential to produce food using ecological methods. Low consumption of fertilisers and crop protection agents, which is usually considered a weakness of Polish agriculture, becomes its advantage, as production area ecological value in agriculture and high biological diversity are among the highest in Europe (Matysik-Pejas, 2008). Although Poland offers good conditions for organic farming, they have not yet been fully used. The delay in organic farming development has several causes. The first one is lack of relevant regulations until 1998, and the second is long-term lack of financial support for farmers, which has not encouraged them to shift to ecological methods (Luczka-Bakula 2007).

Copyright (C) 2017 The Authors. Published by Aleksandras Stulginskis University. This is an open-access article distributed under the terms of the Creative Commons Attribution License (CC-BY 4.0), which permits unrestricted use, distribution, and reproduction in any medium, provided the original author and source are credited. 
Table 1. Advantages of organic farming

\begin{tabular}{|l|l|}
\hline Types of advantages & Characteristics of particular types of advantages \\
\hline Socio-economic & $\begin{array}{l}\text { - prevents excessive rural exodus } \\
\text { - allow maintaining workplaces in rural areas } \\
\text { - low level of support }\end{array}$ \\
\hline Environmental & $\begin{array}{l}\text { - increases soil fertility } \\
\text { - allows maintaining biological diversity } \\
\text { - minimally harmful to the environment }\end{array}$ \\
\hline Health-related & $\begin{array}{l}\text { - assures high nutritional value of products } \\
\text { - provides healthy products }\end{array}$ \\
\hline Ethical and aesthetic & $\begin{array}{l}\text { - preserves diverse landscape of agriculture } \\
\text { - follows environmental ethics principles }\end{array}$ \\
\hline
\end{tabular}

Source: author elaboration basis on (Luczka-Bakula, 2010)

The origins of organic farming in Poland are rooted in the 1930s. In the history of its development in Poland, three main stages can be distinguished (Kowalska, 2010; Golinowska, 2013):

- before 1998, organic farming did not receive any aid from the state budget. The number of organic holdings, owned mostly by hobbyists, was below 500;

- since 1998, holding certification costs have been partially refunded, and in 1999 direct subsidies to arable land area were introduced, which increased the interest in organic farming;

- since 2004, i.e. the year of Poland's accession to the European Union, organic holdings have been developing dynamically due to the introduction of new agricultural programmes co-financed from the European Union budget and the recognition of Polish organic farming certificates by the European Commission, which allowed Polish farmers to sell products on the EU common market.

Between 2004 and 2013, the number of organic agricultural holdings increased from 3,705 to 26,598. In consequence, the area of organic crops increased from 82,730 ha to 669,969 ha. However, in 2014, the trend reversed and the decrease of both values has been observed. In 2016, there were 22,435 organic holdings and the area of organic production agricultural land was 536,579 ha (Table 2).

Table 2. Number of organic farms and area of organic agricultural land in Poland in years 2004-2016

\begin{tabular}{|l|l|l|l|l|l|l|l|l|l|l|l|l|l|}
\hline Year & 2004 & 2005 & 2006 & 2007 & 2008 & 2009 & 2010 & 2011 & 2012 & 2014 & 2015 & 2015 & 2016 \\
\hline $\begin{array}{l}\text { Number of } \\
\text { organic farms }\end{array}$ & 3704 & 7183 & 9189 & 11870 & 14896 & 17091 & 20582 & 23449 & 25944 & 26598 & 24829 & 22277 & 22435 \\
\hline $\begin{array}{l}\text { Area of organic agricultural land } \\
\text { (thousand ha) }\end{array}$ & 82.7 & 166.3 & 228.0 & 287.5 & 314.9 & 416.2 & 519.0 & 605.6 & 661.6 & 669.9 & 657.9 & $\begin{array}{l}580.7 \\
3\end{array}$ & $\begin{array}{l}536.5 \\
8\end{array}$ \\
\hline
\end{tabular}

Source: The report on organic farming in Poland in 2015-2016

The data of the Central Inspectorate of Trade Quality of Agricultural-Food Products shows that in 2016, 83.2\% of all organic farmers operated plant production only holdings, whereas $16.8 \%$ operated holdings with both animal and plant production. Plants intended for feed, grassland, pasture, and cereals prevailed in organic agricultural land $(76.7 \%$ of the crop area in total). Soft fruit plants, fruit trees, vegetables, grain legumes for dry seeds, industrial crops, and potatoes occupied $21.4 \%$ of organic agricultural land area. The remaining crops constituted $1.9 \%$ of agricultural land. (The report on organic farming in Poland in 2015-2016).

The distribution of organic holdings in Poland is diversified in terms of natural and economic conditions in particular provinces. Most organic holdings are located in north-eastern Poland. Organic farming is not an important segment of regional food economy in the Małopolska Province, situated in southern Poland. The total value of organic production in this province is estimated as approx. 0.5\% of the regional agricultural production (PLN 18 million). In 2016, there were 1093 organic agricultural holdings in the Małopolska Province, which constitutes $4.9 \%$ of all organic holdings in Poland, and the area of agricultural land they occupied was 12364.4 ha, i.e. only $2.3 \%$ of all organic agricultural land in Poland. Two holding groups — up to 5 ha (41.8\% and between 5 and 10 ha $(32.3 \%)$ prevailed in the organic holding size structure (Gil, 2016).

\section{RESEARCH METHODS}

The main objective of the conducted research was to present factors determining the operation of organic farms in the conditions of fragmented agriculture in southern Poland. The research was conducted in the Małopolska Province in 2017. The source material used for analysis was primary information collected using the PAPI method. 50 organic farms chosen by using the purposive method of sample selection participated in the survey. The questionnaire included classifying questions allowing the studied sample to be characterized and substantive questions related with the objective of the study. The collected empirical material was analysed using structure indicators and the weighted average expressed by the formula:

$$
\bar{x}=\frac{w_{1} x_{1}+\cdots+w_{n} x_{n}}{w_{1}+\cdots+w_{n}}
$$


where: $\quad \bar{x}$ - weighted average of n scores,

$x_{1}, x_{2} \ldots x_{n}$ - scores,

$w_{1}, w_{2} \ldots w_{n}$ - weights.

\section{RESEARCH RESULTS}

The majority of studied owners of organic farms were men. People between 25 and 35 years old prevailed in the age structure. This may be due to the fact that mostly young people decide to shift from traditional to organic agriculture, as they are not afraid of new organizational and production solutions. The majority of the studied group declared having a secondary education. Education of agricultural producers is a relatively important factor, because a higher level of education may affect the level of ecological awareness and knowledge of the farmers, e.g. regarding the benefits of organic farming, and make them choose this form of agricultural activity more willingly.

Table 3. Demographic profile of the studied organic producers group

\begin{tabular}{|c|c|c|}
\hline \multicolumn{2}{|l|}{ Trait } & Percentage of respondents \\
\hline \multirow{2}{*}{ Gender } & Women & $24 \%$ \\
\hline & Men & $76 \%$ \\
\hline \multirow{6}{*}{ Age } & 24 years & $12 \%$ \\
\hline & 25 to 35 years & $42 \%$ \\
\hline & 36 to 45 years & $18 \%$ \\
\hline & 46 to 55 years & $10 \%$ \\
\hline & 56 to 65 years & $12 \%$ \\
\hline & over 65 years & $6 \%$ \\
\hline \multirow{3}{*}{ Education } & Basic vocational & $24 \%$ \\
\hline & Secondary & $48 \%$ \\
\hline & Tertiary & $28 \%$ \\
\hline
\end{tabular}

Source: own research

Agricultural holdings in the Małopolska Province are quite fragmented and most farmers declared owning an organic holding between 5.1 and $10 \mathrm{~h}$. A trend in accordance to which smallholder farmers choose organic crops, because they can count on EU subsidies and production subsidies, at least during the first years of operation, is visible.

Vegetable production is the most popular type of organic production, as it is conducted in $58 \%$ of the studied holdings. The second most popular direction is fruit farming. The prices of both products are relatively highe $r$ than the prices of conventional products, which improves the economic results of the holdings (Komorowska, 2012). Pigs are bred in $10 \%$ of the holdings, similarly to poultry. Dairy farming was declared in $8 \%$ of the organic holdings. These production directions require bigger labour outlays and are typical for traditional farming (Gil, 2016) of the Małopolska Province.

Table 4. Characteristics of the studied organic holdings

\begin{tabular}{|l|l|c|}
\hline Trait & Up to 5.0 ha & Percentage of holdings \\
\hline \multirow{4}{*}{ Organic holding size } & 5.1 to 10.0 ha & $10 \%$ \\
\cline { 2 - 3 } & 10.1 to 20.0 ha & $32 \%$ \\
\cline { 2 - 3 } & 20.1 to 30.0 ha & $20 \%$ \\
\cline { 2 - 3 } & Over 30.0 ha & $22 \%$ \\
\hline \multirow{4}{*}{ Type of organic holding } & Vegetable production & $16 \%$ \\
\cline { 2 - 3 } & Fruit production & $58 \%$ \\
\cline { 2 - 3 } & Poultry breeding & $12 \%$ \\
\cline { 2 - 3 } & Pigs breeding & $10 \%$ \\
\cline { 2 - 3 } & Dairy cattle breeding & $10 \%$ \\
\cline { 2 - 3 } & Herbs production & $8 \%$ \\
\hline \multirow{2}{*}{$\begin{array}{l}\text { Length of the period of operating an organic } \\
\text { conducted }\end{array}$} & 2 years & $2 \%$ \\
\cline { 2 - 3 } & 3 to 5 years & $34 \%$ \\
\cline { 2 - 3 } & 6 to 10 years & $28 \%$ \\
\cline { 2 - 3 } & over 10 years & $14 \%$ \\
\hline
\end{tabular}

Source: own research

One of the main reasons encouraging farmers to shift from conventional to organic agriculture is the possibility of obtaining subsidies for the holding's profile. This answer had the highest average score (4.44) on a five-grade scale. Subsidies allow farmers to introduce changes in their holdings and improve conditions of farming and holding members' lives (Kisiel, Grabowska, 2014). Another important reason for changing the holding's profile is the willingness to offer higher quality products on the market (average score 4.38), as organic farming systems are able to produce food meeting high quality standards (Lairon, 2010). The possibility of choosing holding's profile turned out to be slightly less important. It is a bit worrying that the factors related with decreasing environmental pollution were considered the least important in the studied group. 
Table 5. Reasons of shifting from conventional to organic farming

\begin{tabular}{|l|c|c|c|c|c|c|}
\hline \multirow{2}{*}{ Specification } & \multicolumn{3}{|c|}{ Indicators of scoresof particular factors } & \multirow{2}{*}{$\begin{array}{c}\text { Average } \\
\text { score }\end{array}$} \\
\cline { 2 - 6 } & 1 & 2 & 3 & 4 & 5 & 2.4 \\
\hline Possible subsidies for the holding's profile & $2 \%$ & $2 \%$ & $10 \%$ & $22 \%$ & $64 \%$ & 4.44 \\
\hline Higher products quality & $2 \%$ & $4 \%$ & $4 \%$ & $34 \%$ & $56 \%$ & 4.38 \\
\hline Possibility of specialising the holding in a given direction & $2 \%$ & $20 \%$ & $22 \%$ & $28 \%$ & $28 \%$ & 3.60 \\
\hline Lower environmental pollution & $8 \%$ & $12 \%$ & $28 \%$ & $26 \%$ & $26 \%$ & 3.50 \\
\hline
\end{tabular}

Source: own research

Sustainable organic production consists of appropriate crop rotation and other natural methods of maintaining or increasing biological activity of the soil. It is also related with the welfare of plant species and varieties and animal species and races taking their natural immunity to diseases and adaptation to the local climate into account. The context also includes the answers of the studied group of farmers, who consider the possibility of choosing plant and animal species that are immune to diseases (average score 4.42). The respondents also stated that organic farming systems create new workplaces (average score 4.12) due to the work intensity of organic production. Thus, organic farming helps stimulate the local economy and community. The farmers awarded a lower score to the statement that the development of organic farming stimulates the development of the processing industry. Sadly, in Poland the links between organic farmers and the processing industry are still not strong enough. The flow of information between them, concerning farmers' offers and processors' needs, is too weak. The possibility of exporting the produced organic food had the lowest score. This may be due to the fact that this is a distant perspective for most respondents, although an increasing number of Polish organic food products succeed in finding their outlet outside the borders of Poland, which allows the producers to sell for better prices.

Table 6. Investment advantages of organic farming according to organic producers

\begin{tabular}{|l|c|c|c|c|c|c|}
\hline \multirow{2}{*}{ Specification } & \multicolumn{3}{|c|}{$\begin{array}{c}\text { Indicators of scores } \\
\text { of particular factors }\end{array}$} & \multirow{2}{*}{$\begin{array}{c}\text { Average } \\
\text { score }\end{array}$} \\
\cline { 2 - 7 } & 1 & 2 & 3 & 4 & 5 & 4.42 \\
\hline Possibility of choosing plant and animal species immune to diseases & $4 \%$ & $4 \%$ & $4 \%$ & $22 \%$ & $66 \%$ & $4 \%$ \\
\hline Creation of new workplaces & $8 \%$ & $4 \%$ & $20 \%$ & $20 \%$ & $48 \%$ & 4.12 \\
\hline Impact on the development of the processing industry & $2 \%$ & $8 \%$ & $40 \%$ & $8 \%$ & $42 \%$ & 3.80 \\
\hline Possibility of products export & $16 \%$ & $24 \%$ & $28 \%$ & $12 \%$ & $20 \%$ & 2.96 \\
\hline
\end{tabular}

Source: own research

The distribution of scores regarding the possible weaknesses of organic farming allows concluding that all the listed variants are important for the respondents, as the score of 4 or 5 points on a five-grade scale was quite popular. The producers considered the difficulties in winning new sale markets the biggest disadvantage of organic farming. Farmers have been struggling with this problem for years. The problem is due to the high dispersion of holdings and their relatively small areas, as well as their distance from big agglomerations, where the demand for organic food accumulates. Organic food producers usually use non-formalized sales forms, among which a direct sale in the holding is the most popular. Reluctance towards association with other farmers despite the fact that it would make negotiations and introducing the products to the market easier is a weakness of organic farmers (Nowogrodzka, 2012). The producers consider demand another weakness, although its continuous increase is observed. There are several reasons, such as the lack of consumer awareness regarding the advantages of organic food and farming, too high prices of organic products, limited assortment, lack of consumer knowledge about marking of such products and places where they are sold (Zakowska-Biemans, 2011; Matysik-Pejas et al., 2017).

Table 7. Disadvantages of organic farming according to organic producers

\begin{tabular}{|l|c|c|c|c|c|c|}
\hline \multirow{2}{*}{ Specification } & \multicolumn{3}{|c|}{ Indicators of scores of particular factors } & \multicolumn{2}{c|}{$\begin{array}{c}\text { Average } \\
\text { score }\end{array}$} \\
\cline { 2 - 7 } & 1 & 2 & 3 & 4 & 5 & 7.40 \\
\hline Difficulties in winning new sale markets & $4 \%$ & $6 \%$ & $6 \%$ & $14 \%$ & $70 \%$ & $4 \%$ \\
\hline Insufficient organic food popularity & $4 \%$ & $6 \%$ & $10 \%$ & $24 \%$ & $56 \%$ & 4.22 \\
\hline Yields lower than in conventional agriculture & $2 \%$ & $6 \%$ & $20 \%$ & $22 \%$ & $50 \%$ & 4.12 \\
\hline
\end{tabular}

Source: own research

The farmers from the studied group actively participate in educational trainings in order to expand their knowledge on organic production. They acquire new skills and qualifications regarding organic plant and animal production, so they are able to compete with producers from other regions. Education is also an important element of shaping ecological awareness and promoting sustainable development principles. At the same time, farmers are insufficiently involved in educational activity in their environment. Educational activities for children or people interested in ecology were conducted in only $16 \%$ of the studied holdings, although they can be an important element of the holding's products promotion, future consumers' attitude shaping, as well as improving the understanding of advantages of organic farming systems in rural areas.

\section{CONCLUSIONS}

Organic farming in the Małopolska Province is based on a traditional model. Producers focus mostly on fruits and vegetables. This is due to the high fragmentation of holdings in this region and the opportunities to use the surplus of the 
workforce. The percentage of holdings producing herbs or breeding animals gives hope for the development of organic farming also in these areas. This is important in the context of the diversification of the organic products offer that encourages consumers to purchase them. Organic food may become an identification mark of small specialised holdings in the Małopolska Province. Starting the operation of an organic holding is usually motivated by subsidies that can be obtained after conversion to organic farming. Such subsidies provide significant support during the first years on the market. Research results allow concluding that farmers consider the lack of a sale market for their products and the low popularity of organic food among consumer to be the basic problems. The appropriate promotion and distribution of organic food, as well as efficient information about the advantages of organic products could improve this situation. At the same time, a vast majority of the studied group of farmers does not carry out educational activities that could bring up new organic food consumers.

\section{REFERENCES}

1. Gil A. 2016. Innovation in fragmented agriculture on the example of organic farms in the małopolskie voivodship. Rural Studies, Vol. 42, pp. 197-208.

2. Golinowska M. 2013. Development of organic farming, University of Life Sciences, Wroclaw. Available at: http://www.rcin.org.pl/igipz/Content/61626/WA51_80948_r2016-t42_SOW-Gil.pdf

3. Kisiel R., Grabowska N. 2014.The role of European Union subsidies in the development of organic farming in Poland - an example of Podlasie region. Water-Environment-Rural Areas. Vol. 14, Iss. 3 (47), pp. 61-73. http://yadda.icm.edu.pl/baztech/element/bwmeta1.element.baztech-35350414-b6d8-4b0e-b8bb-57447bfcf681

4. Komorowska D. 2012. Production organization and economic performance of organic farms of different size groups. Economics and Organization of Agri-Food Sector, Vol. 95, pp. 41-52. http://www.wne.sggw.pl/czasopisma/pdf/EIOGZ_2012_nr95.pdf

5. Kozlowski S. 2000. Eco-development - challenge of the XXI century, PWN, Warszawa.

6. Kowalska A. 2010. The determinants of organic agriculture development in Poland and in other European countries. Annales Universitatis Mariae Curie-Skłodowska, Sectio H Oeconomia, Vol. XLIV, pp. 47-63. http://yadda.icm.edu.pl/yadda/element/bwmeta1.element.ekon-element-000170903123

7. Lairon D. 2010. Nutritional quality and safety of organic food. A review. Agronomy for Sustainable Development, Vol. 30, Issue 1, pp 33-41. https://doi.org/10.1051/agro/2009019

8. Luczka-Bakula W. 2007. The organic food market - the determinants and conditions of development. PWE, Warszawa. MatysikPejas R. 2008. Development processes of the organic farming in Poland in years 2003-2007. Problems of World Agriculture, Vol. 4(19), pp. 309-317. http://www.wne.sggw.pl/czasopisma/pdf/PRS_2008_T4(19).pdf

9. Matysik-Pejas R., Szafranska M., Horska E. 2017. Factors affecting consumer buying process of organic food in Krakow urban area. Economic Science for Rural Development Conference Proceedings, Iss. 45, pp.314-321, Latvia University of Agriculture. http://llufb.1lu.1v/conference/economic_science_rural/2017/Latvia_ESRD_45_2017.pdf

10. Nowogrodzka T. 2012. Current status and prospects of organic farming in Poland. Problems of World Agriculture, Vol. 12(27), Iss. 2, pp. 54-65. http://www.wne.sggw.pl/czasopisma/pdf/PRS_2012_T12(27)_z2.pdf

11. Soltysiak U. 1994. Organic farming in practice. EKOLAND Stiftung Leben\&Umwelt, Warszawa.

12. The report on organic farming in Poland in 2015-2016. Warszawa. https://www.teraz-srodowisko.pl/media/pdf/aktualnosci/3861raport-o-stanie-rolnictwa-ekologicznego-w-polsce-w-latach-2015-2016.pdf

13. Weglarzy K., Bereza M. 2010. Organic farms as an alternative to conventional farms in terms of production profitability (in:) Rural areas and agriculture in the process of change. Problems of the transformation of European agriculture, S. Sokołowska, A. Bisaga (edt.). University of Opole, pp. 175-198.

14. Zakowska-Biemans S. 2011. Barriers to buy organic food in the context of organic food market development. Journal of Research and Applications in Agricultural Engineering, Vol. 56(4), pp. $\underline{\text { http://yadda.icm.edu.pl/baztech/element/bwmeta1.element.baztech-article-BAR8-0014-0044 }}$ 